\title{
The Politics of Mythmaking: Foreign Policy in Canadian Federal Elections 1958-1965
}

\author{
Kristopher Kinsinger
}

Discussions on the history of Canadian foreign policy have often centered around the style of diplomacy practiced by the country's leaders in the decades immediately following the Second World War. Such histories tend to describe these years as a "golden age" for Canadian foreign policy, a time when the country was able to able to "punch above its own weight" by fostering constructive international solutions such as peacekeeping at multilateral forums like the United Nations. Recent scholarship however, has challenged this narrative describing a much different approach to foreign policy during the postwar years than what Canadians have largely come to remember. Canada was less of a "helpful fixer" during this era than it was a country continually restricted by its limited influence on the world stage. While Canadian politicians such as Lester B. Pearson may have held lofty ideals of international peace and stability, they were constantly forced to conduct foreign policy through the auspices of the United States and Great Britain, Canada's key North Atlantic allies. ${ }^{1}$

While many historians have laudably deconstructed the mythological notion of a Canadian foreign policy "golden age," historical scholarship has done comparatively little to evaluate when and how this mythology developed. Substantive differences in the actual foreign policies implemented by successive Liberal and Conservative governments during the 1950s and

\footnotetext{
${ }^{1}$ Asa McKercher, "The Centre Cannot Hold: Canada, Colonialism and the 'Afro-Asian Bloc' at the United Nations, 1960-62," The Journal of Imperial and Commonwealth History 24, no. 2 (2014): 329; Greg Donaghy, "Canadian Diplomacy and the Offshore Islands Crisis, 1954-1955: A Limited National Interest," International Journal 68, no. 2 (2013): 242-245; Hector Mackenzie, "Knight Errant, Cold Warrior or Cautious Ally? Canada on the Untied Nations Security Council, 1948-1949,” Journal of Transatlantic Studies 7, no. 4 (2009): 453-457.
} 
60s were for the most part minimal. ${ }^{2}$ Yet by the time Pearson stepped down as prime minister in 1968, "golden age" symbolism and language had come to govern discourse on Canadian external affairs. Partisan messaging thus becomes an apt field for study in assessing what factors contributed to the emergence of a "golden age" narrative during this time. This paper aims to begin to fill this gap in the historiography of Canadian foreign policy by considering how political rhetoric aided the development of "golden age" mythology from its supposed end in the late 1950s up to the beginning of Pearson's second mandate as prime minister. To this end the majority of this paper will be devoted to conducting individual case studies for the 1958, 1962, 1963 and 1965 federal elections in order to analyze how both major parties' rhetoric concerning foreign policy evolved over the course of this period. ${ }^{3}$ This analysis will reveal that the Liberals were the most active and vocal supporters of "golden age" mythmaking during these elections and as such the foreign policy messaging of the Liberal Party will be given special attention in these studies.

It was clear from the outset that the 1958 federal election would revolve primarily around domestic policy. With a faltering economy and unemployment rates steadily creeping higher Canadians had little desire to spend time dwelling on issues that lay beyond their borders. Yet more fundamentally, the campaign was a referendum on whether the Liberals deserved to be restored to government after their narrow defeat at the hands of John Diefenbaker's Conservatives in the previous year's election. Even before the writ was dropped this question had come to dominate Canadian political discourse on both sides of the aisle.

\footnotetext{
${ }^{2}$ John T. Saywell, edit., Canadian Annual Review for 1962 (Toronto: University of Toronto Press), 102.

${ }^{3}$ Although other parties such as the Cooperative Common Federation (later the New Democratic Party) and the Social Credit Party articulated full foreign policies of their own during these elections, this paper will focus only on the foreign policies of the more prominent Liberal and Progressive Conservative parties due to spatial constraints.
} 
Following his defeat in 1957, it soon became clear that Louis St. Laurent's deteriorating health would not allow him to lead the Liberals into the next election. Lester B. Pearson, one of St. Laurent's ablest ministers, was persuaded to seek the leadership at the party's national convention (only the fourth since Confederation) in January of $1958 .{ }^{4}$ Pearson's impressive career at the Department of External Affairs had earned him numerous plaudits within the party, allowing him to handily claim the leadership with $77.8 \%$ of support on the first ballot. Many of the speeches and resolutions of the 1958 Liberal convention provide useful insight into the party's self-image during the lead-up to the election later that year. On the first day of the convention former citizenship and immigration minister Jack Pickersgill waxed about how at their core the Liberals had always championed a distinct Canadian identity and citizenship that was independent of the British Empire: "By instinct, and often by interest, the Tories stood for the dependency and subjection of the new settlements to the mother country, and they were content to be called subjects; while the political and spiritual ancestors of the Liberals contended, from the earliest times, that free born Englishmen brought their rights with them across the Atlantic. It is that insistence on the rights of free men that is the real germ of Canadian citizenship. ${ }^{\circ}$

Pickersgill's convention speech was almost certainly a rebuke of the symbolic shift Canadian foreign policy had taken during the first year of Diefenbaker's premiership. ${ }^{6}$ As much of the Conservative base consisted of Canadians who held a strong attachment to Canada's British heritage, Diefenbaker had pursued a foreign policy that sought to strengthen Canadian ties to the Commonwealth. The Liberals in contrast attempted to define Canada's identity as

\footnotetext{
${ }^{4}$ National Liberal Convention - Report on the Proceedings (Ottawa: National Liberal Federation of Canada, 1961), 245.

${ }^{5}$ Ibid., 40.

${ }^{6}$ Greg Donaghy, edit., Documents on Canadian External Relations: Vol. 24 (Ottawa: Department of External Affairs, 2003), xi.
} 
having outgrown its colonial past. As Pickersgill proclaimed later in the same speech this unique independent identity had allowed the country to adopt a "special national character" in international affairs. As evidence he pointed specifically to the Nobel Peace Prize Pearson had won for his involvement in the creation of the United Nations Emergency Force:

Because we have learned to live in peace and, often, even in friendship with our neighbours inside Canada, it seems natural for Canadians to look for peace, and even for friendship, with other nations outside Canada. That is why it seems to me no accident that a great Canadian who happens also to be a great Liberal should have been the winner of the Nobel Peace Prize. Lester Pearson, the man of peace and good will, is in the Canadian tradition. It is our native Canadian tradition of peaceful co-existence slowly mellowing into mutual good will that makes our Canadian citizenship of value not only to ourselves but to the rest of this troubled world. ${ }^{7}$

The address by Pickersgill illustrates how the "golden age" of Canadian diplomacy was already becoming a key pillar of the Liberal brand by the end of the 1950s. Such posturing would become common during Pearson's tenure as Liberal leader, as the Grits strove to differentiate themselves from the Tories by insisting that they were the true defenders of this unique "Canadian tradition." Yet upon Pearson's return to Parliament and throughout the election later that year, the new Liberal leader struggled to outpace the Conservative prime minister. During Pearson's first address in the House of Commons as leader of the official opposition on January 20 he accused the Conservatives of mishandling Canada's economy, proposing that should the prime minister and his cabinet step down they could be replaced by "a government pledged to implement Liberal policies." ${ }^{8}$ Diefenbaker was merciless in his blistering retort. For over two hours the prime minister railed against Pearson, producing a secret economic outlook prepared for the previous Liberal government that suggested St. Laurent and Pearson had known about the

\footnotetext{
${ }^{7}$ National Liberal Convention, 42.

${ }^{8}$ John English, The Worldly Years: The Life of Lester Pearson, 1949-1972 (Toronto: Alfred A. Knopf Canada, 1992), 200.
} 
oncoming economic downturn during the 1957 election. By the end of the exchange an election appeared all but inevitable. ${ }^{9}$ Diefenbaker met with the Governor General twelve days later, and an election was called for March $31 .^{10}$

Diefenbaker's 1958 campaign was built around two key messages. The first was a denunciation of the Liberals' suggestion that they be restored to government without calling an election. Diefenbaker masterfully turned the Liberals' own branding tactics against them, framing their earlier attempt to retake their "rightful place as the Government of Canada" as the arrogance of a tired regime that had long outworn its usefulness. ${ }^{11}$ The second was what Diefenbaker came to refer to throughout the 1958 campaign as his overarching "Vision" for the country in which "Canadians will have preserved to them the control of their own economic and political destiny." 12 This platform accordingly promised jobs for "hundreds of thousands of Canadians" through a national economy driven by the development of Canada's vast northern resources. ${ }^{13}$ The rhetoric of the "Vision" allowed Diefenbaker to ably undercut the Liberals' insinuation that they better embodied Canada's "special national character" while also proposing an alternative (but not necessarily contradictory) view of what the Liberal's 1958 platform had termed "Canadianism."14

Although the "Vision" was primarily domestic in its scope it significantly impacted how the Tories framed their foreign policy in the 1958 election. As Diefenbaker later recalled in his

\footnotetext{
${ }^{9}$ Denis Smith, Rogue Tory: The Life and Legend of John G. Diefenbaker (Toronto: MacFarlane Walter \& Ross, 1995), 533; Carrigan, Canadian Party Platforms, 278.

${ }^{10}$ English, The Worldly Years, 200-201.

${ }^{11}$ Peter C. Newman, Renegade in Power: The Diefenbaker Years (Toronto: McClelland and Stewart, 1964), 66; As journalist Peter C. Newman summed up the Liberal's proposal that they retake government without an election. ${ }^{12}$ Newman, Renegade in Power, 69-70; Bruce Thordarson, Lester Pearson: Diplomat and Politician (Toronto: Oxford University Press, 1974), 105.

${ }^{13}$ Newman, Renegade in Power, 70.

${ }^{14}$ D. Owen Carrigan, edit., Canadian Party Platforms, 1967-1968 (Toronto: Copp Clark Publishing Company, 1968), 244. This useful collection of primary sources contains official platforms and statements from both the Liberals and the Conservatives for each of the elections being studied, and as such it is extensively cited throughout this paper.
} 
memoirs, "The basis of our future greatness lay in our ability to exploit, in the interest of all Canadians and not of foreign entrepreneurs, the vast treasure-house that the Almighty had provided us in the Canadian North." 15 Throughout the campaign, Diefenbaker criticized the Liberals for previously allowing the shipment of raw Canadian minerals to the United States rather than having these resources processed in Canada. At an event in Edmonton on March 8, Diefenbaker maintained "It doesn't make sense to me that the Liberal party by 1959 planned to be able to ship 10,000,000 tons of iron are [sic] annually into the United States there to provide jobs in the manufacture of articles to be shipped back to Canada to increase the trade deficit with that country." 16 The trade deficit with the United States became a recurring theme for the Tories throughout the election, with Diefenbaker promising to rectify the problem by continuing to divert imports from the United States to the United Kingdom, building on his previous commitments to strengthen Canada's ties to the Commonwealth. ${ }^{17}$

Similarly, while the Liberal Party's official 1958 platform mostly focused on domestic issues such as cutting taxes and increasing social security, it did contain several important passages devoted to foreign policy. Incorporating resolutions adopted at the party's convention from earlier in the year, the platform's section on external affairs once again employed the emerging language and symbolism of the "golden age" mythology, being rooted in the premise that "Canada's active role in world affairs as an independently minded middle power is now a vital aspect of her nationhood." ${ }^{18}$ Pearson's Liberals declared that Canadian foreign policy must be based on a commitment to facilitating peaceful, constructive solutions to international

\footnotetext{
${ }^{15}$ John G. Diefenbaker, One Canada: Memoirs of the Right Honourable John G. Diefenbaker - Volume Two: The Years of Achievement, 1956-1962 (Scarborough: Signet, 1976), 69.

${ }^{16}$ Diefenbaker's Statements and Promises, 1958 (Ottawa: National Liberal Federal, 1958), P4, accessed December 2, 2015, https://www.poltext.org/sites/poltext.org/files/plateformes/can1958pc_plt_29032012_161629.pdf.

${ }^{17}$ Diefenbaker's Statements, T5-T6.

${ }^{18}$ Carrigan, Canadian Party Platforms, 242.
} 
disputes through multilateral organizations such as the United Nations and NATO. Canada's role in the creation of the United Nations Emergency Force was once again highlighted, with the Liberals promising that they would "support UNEF as long as it continues to be necessary for peace" in the Middle East. ${ }^{19}$ The actions of the Soviet Union were likewise a pressing and immediate concern, with the Liberals maintaining that the "eventual liberation [of those peoples who remain unwillingly under Soviet control] is dependent upon a creative peace that alone will provide the chance of their return to independence. ${ }^{" 20}$ While the Liberals (like the Conservatives) also envisioned closer economic ties between Canada and the Commonwealth, their trade policies marked a clear departure from Diefenbaker's anti-American rhetoric. Condemning trade restrictions as a form of economic isolationism the party held that "expansion not diversion of trade is the only policy compatible with sound, rapid economic development and with increasing productivity and living standards." 21

Although both parties' foreign policies underscored the significant symbolic differences between their respective political brands, these issues ultimately had a minimum impact on the outcome of the 1958 election. Diefenbaker's charisma and emotional idealism enraptured Canadians from coast to coast, while Pearson, more accustomed to the nuance of the Department of External Affairs than the rhetoric of election campaigns, came across as timid and uninspiring. ${ }^{22}$ On election night the Conservatives captured 208 seats, up to that point the largest majority in Canadian history, while the Liberals were shut out in all but four provinces and reduced to a caucus of forty-eight members, its smallest since Confederation. ${ }^{23}$

\footnotetext{
${ }^{19}$ Carrigan, Canadian Party Platforms, 243.

${ }^{20}$ Ibid., 244.

${ }^{21}$ Ibid., 246.

22 Thordarson, Diplomat and Politician, 105.

${ }^{23}$ Newman, Renegade in Power, 76; Carrigan, Canadian Party Platforms, 235; The final seat-counts for the other parties were: Cooperative Commonwealth Federaion, 8; other, 1.
} 
Several important foreign policy issues were debated amongst Canadian politicians during the course of Diefenbaker's only majority mandate. Decolonization and peacekeeping in Africa and the Middle East, the valuation of the Canadian dollar on the Common Market and the nature of Canada's role in the Cold War are just a few examples of the foreign policy issues that arose between the 1958 and 1962 elections. ${ }^{24}$ By the time of the 1962 election, however, such issues had been eclipsed by widespread concern over the onset of yet another recession, an anxiety which the Liberals sought to exploit. The four years since the previous election had allowed Pearson to hone his political instincts and streamline his party's operations. Keith Davey, Pearson's 1962 campaign manager, structured the Liberal campaign around three key objectives: to attack the performance of the Diefenbaker government; to promote the Liberals" "positive programs" for jobs and prosperity; and to improve the public perception of Pearson's leadership by surrounding him with a strong core team of candidates. ${ }^{25}$ The Liberal Party consequently focused the majority of its platform on its revitalized domestic agenda. ${ }^{26}$ Yet even with this increased attention to domestic issues, the Grits continued to subtly harken back to "golden age" symbolism throughout the 1962 campaign.

As in 1958, the Liberal's foreign policy in the 1962 election was rooted in a commitment to multilateralism, foreign aid and constructive diplomacy. Although in practice such policies had never really been abandoned since the Conservatives had taken office, the thrust of this message was that Canada needed to recommit itself to the "spirit" of traditional (i.e. "golden age") Canadian postwar diplomacy. ${ }^{27}$ The section on "Our Place in the World" declared that

\footnotetext{
${ }^{24}$ Saywell, Canadian Annual Review for 1962, 102; Kevin Spponer, "Just West of Neutral: Canadian "Objectivity" and Peacekeeping during the Congo Crisis," Canadian Journal of African Studies 43 no 2. (2009): 304-308.

${ }^{25}$ Keith Davey, The Rainmaker: A Passion for Politics (Toronto: Stoddart, 1986), 53-55.

${ }^{26}$ In 1958, "External Affairs" had been one of the first sections of the Liberal platform, whereas in 1962 a much shorter section on "Our Place in the World" was relegated to the end of the programme.

${ }^{27}$ Carrigan, Canadian Party Platforms, 269.
} 
"Canada's ability to influence world affairs depends on the respect in which we are held. This in turns depends on working steadily and cooperatively with our allies ... [and] requires diplomacy that is strong but quiet, that is concerned with results rather than with rhetoric." ${ }^{28}$ While Diefenbaker's foreign policies were never specifically referenced or criticized in the 1962 platform, the Liberals insinuated that Canada's international reputation had suffered since the party had been removed from office in 1957. At times the programme was almost nostalgic in its tone bemoaning the country's lost prestige and promising to "Restore respect for Canada and build Canada's influence for world peace."29

The charge that Canada's influence on the world stage had waned since 1957 was advanced more unequivocally on the hustings by prominent Grit candidates. Paul Martin, who would later become Pearson's secretary of state for external affairs, denounced Diefenbaker for devaluing the Canadian dollar and for opposing Britain's admission into the European Common Market, the latter of which he claimed would sully Canada's reputation amongst the country's allies. ${ }^{30}$ Conservative responses to such criticisms are revealing in several key respects. At times the Tories almost seemed to welcome the Liberals' use of such nostalgic "golden age" imagery, using these appeals as an opportunity to undermine in the eyes of the public, what many Grits had come to consider to be one their party's core strengths. In January of 1962 several months before the writ dropped Diefenbaker accused Pearson in the House of being "soft on Communism." Less than two months later Harry O. White, the Tory backbencher for Middlesex East, took this charge one step further. While in the past Conservatives had generally been

\footnotetext{
${ }^{28}$ Carrigan, Canadian Party Platforms, 269.

29 Ibid.

${ }^{30}$ Paul Martin, A Very Public Life - Volume II: So Many Worlds (Toronto: Deneau Publishers, 1985), 346; Saywell, Canadian Annual Review for 1962, 104; Although the Liberals spent a large portion of their campaign attacking Diefenbaker for his decision to peg the Canadian dollar at \$0.95 USD, this criticism was ultimately more about the Conservatives' broader economic stewardship than it was Canada's reputation abroad.
} 
careful not to criticize Pearson's Nobel Prize winning role in the creation of the 1957 United Nations Emergency Force, White held that Pearson had only won the award by siding with the Communists against Canada's allies. ${ }^{31}$ The Liberals responded by pointing out that Pearson had on more than one occasion been barred from the UN Secretary Generalship by the Soviet Union, but the comment from White ultimately passed without any denunciation from Diefenbaker. ${ }^{32}$

The accusation that Pearson was "soft on Communism" was a motif that came to be repeated by the Conservatives throughout the 1962 election. In May Diefenbaker denied ever having used these exact words, yet persisted to condemn the Liberals for not having done enough while in office to oppose Soviet colonialism: "What I said was that, during the years 1945-57 nothing had ever been done or said by Mr Pearson as external affairs minister or by Paul Martin at the United Nations respecting the very serious situation of colonialism in the USSR or the tyranny perpetrated by the USSR on captive people. This was due to a failure to recognize the problem. ${ }^{" 33}$ In contrast the Tories sought to cast their leader as a hardened Cold Warrior who had gained widespread respect on the world stage. One Conservative campaign pamphlet boasts of how British prime minister Harold Macmillan had described Diefenbaker's "strong United Nations speech answering Soviet Premier Khrushchev as 'arresting' and 'brilliant," while also highlighting the "unanimous approval" Diefenbaker's plan for a World Food Bank program received at the General Assembly. ${ }^{34}$

\footnotetext{
${ }^{31}$ At the start of the Suez Crisis many Conservatives had condemned the Liberal government for its unwillingness to support Great Britain and France in the conflict. Nevertheless, the Tories were generally hesitant to outright denounce Pearson's part in devising the eventual peacekeeping solution. Diefenbaker's later support as prime minister for a the similar United Nations Operations in the Congo made it much more difficult for the Conservatives to subsequently attack the Liberals' much-touted commitment to peacekeeping.

${ }^{32}$ Saywell, Canadian Annual Review for 1962, 104.

${ }^{33}$ Saywell, Canadian Annual Review for 1962, 104; In his sardonic response to the prime minister's accusations Pearson contended that "I was fighting communism at the United Nations before Mr Diefenbaker had ever heard of it."

${ }^{34}$ Getting Things Done for Canadians - An Outline of Progressive Conservative Government Action, 1957-1962: The Greatest Era of Expansion in Canada's History (Ottawa: Progressive Conservative Party of Canada, 1962), 10
} 
In spite of occasional back-and-forth rhetoric over Canada's international reputation and the fight against Communism, issues of foreign policy although slightly more important than they had been in 1958, had a limited impact on the outcome of the 1962 election. Diefenbaker failed to capture the imagination of Canadians in the way that he had in the previous two elections, and Pearson rebounded from his poor premiere as Liberal leader with a newfound energy and appeal. The Conservatives went to great lengths to boast of their record in office and to emphasize the promises they had kept since the last election, with Diefenbaker insisting that "Canada never had it so good." Nevertheless, a persistently high unemployment rate had left many Canadians with a desire for change in Ottawa, allowing the Liberals to double their representation in Parliament to ninety-nine seats after their disastrous showing in the last election. Despite still being in opposition, Pearson and the Liberals had positioned themselves within striking distance of Diefenbaker's much-diminished 116 seat government. ${ }^{35}$

An analysis of foreign policy in the April 1963 election would be incomplete without a description of the events which culminated in the Diefenbaker government's defeat in the House of Commons in February earlier that year. During the brief respite between elections, Diefenbaker's indecision over whether to accept American nuclear warheads for Canada's NATO air contingent threatened to tear the Tory caucus apart with the crisis reaching a critical mass by January. In an address to the House on January 25 Diefenbaker attempted to clarify Canada's nuclear position by stating that "nuclear weapons would be secured in the event circumstances made such a course necessary." ${ }^{36}$ Yet in the same speech the prime minister also managed to stimulate even more confusion by declaring that "More and more the nuclear

\& 15, accessed December 2, 2015;

https://www.poltext.org/sites/poltext.org/files/plateformes/can1962pc_bilan_18072011_155924.pdf.

35 Carrigan, Canadian Party Platforms, 258-259; The final seat-counts for the other parties were: New Democratic, 19; Social Credit, 30; other, 1.

${ }^{36}$ Newman, Renegade in Power, 366. 
deterrent is becoming of such a nature that more nuclear arms will add nothing material to our defence. ${ }^{\prime 37}$ Members of the Canadian press interpreted this line as a possible indication that the country was about to withdraw from nuclear commitments. ${ }^{38}$ Five days later the American State Department issued a blistering press release that contradicted Diefenbaker's assertion that Canada would acquire nuclear weapons if necessary, stating that "The Canadian Government has not yet proposed any arrangements sufficiently practical to contribute effectively to North American defence. ${ }^{.39}$

Diefenbaker's equivocation on the nuclear question set the stage for his government's defeat in the House on February 6. Three days earlier he had convened an informal cabinet meeting at his official residence during which George Hees, the minister of trade and commerce, implored the prime minister to once and for all clarify his nuclear stance. This was followed up by a virulent condemnation from the minister of national defence Douglas Harkness, who contended that Diefenbaker had lost the confidence of cabinet. When Diefenbaker asked those ministers who still supported him to stand up, nine remained in their seats. The meeting ended with both Harkness and the prime minister stating that they would resign. ${ }^{40}$

Diefenbaker (unsurprisingly) quickly reversed his decision to step down, ignoring other last-minute appeals from several members of his cabinet to resign before the inevitable nonconfidence motion. ${ }^{41}$ Harkness delivered his official resignation in the House on February 4, which he asserted was a "matter of principle." 42 Shortly afterwards Pearson rose to deliver a motion of non-confidence. The official text read: "this government, because of lack of

\footnotetext{
${ }^{37}$ Newman, Renegade in Power, 361.

${ }^{38}$ Ibid.

${ }^{39}$ Ibid., 366.

${ }^{40}$ John Saywell, Canadian Annual Review for 1963 (Toronto: University of Toronto Press, 1964), 8-9.

${ }^{41}$ Smith, Rogue Tory, 487-488; At a cabinet meeting on February 6, Diefenbaker successfully convinced all but two of his ministers to support the government in the upcoming non-confidence motion.

${ }^{42}$ Newman, Renegade in Power, 365.
} 
leadership, the breakdown of unity in the cabinet, and confusion and indecision in dealing with national and international problems, does not have the confidence of the Canadian people." ${ }^{23}$ This was followed by an amended motion put forth by Robert Thompson, leader of the Social Credit Party, which more specifically condemned the government for having "failed up to this time to give a clear statement of policy respecting Canada's national defence..." ${ }^{44}$ The final count for both motions the following evening was 142 in favour and 111 against, with two Conservative members absent and another one abstaining. ${ }^{45}$

Diefenbaker's nebulous policy on nuclear weapons continued throughout the Conservatives' 1963 campaign. In the speech he made just before the government fell, the prime minister had promised "flexibility" regarding the nuclear issue, committing to a final decision by the next NATO council meeting in May and vowing that nuclear warheads could readily be acquired if necessary. ${ }^{46}$ Two weeks later, however, Diefenbaker asserted in a campaign speech that Canada's existing NATO arsenal was "useless even when armed with nuclear weapons.... They are only being retained because of the investment." ${ }^{\text {47 }}$ The resignation of cabinet ministers George Hees and Pierre Sévigny shortly after the start of the campaign only compounded the perception that Diefenbaker lacked direction on the nuclear issue, with both ministers accusing the prime minister of abandoning Canada's NATO commitments. ${ }^{48}$ The reasons for the prime minister's vacillation on the issue of nuclear weapons (particularly after the Tories attempts in

\footnotetext{
${ }^{43}$ Saywell, Canadian Annual Review for 1963, 9.

${ }^{44}$ Ibid., 10; The full amended motion from Thompson read: "This government has failed up to this time to give a clear statement of policy respecting Canada's national defence, and has failed to organize the business of the House so that the 1963-64 estimates and budget could be introduced, and has failed to outline a positive program of followup action respecting many things for which this parliament and previous parliaments have already given authority, and does not have the confidence of the Canadian people."

${ }^{45}$ Newman, Renegade in Power, 374; The absentee Tories were Art Smith (Calgary South) and former national defence minister Douglass Harkness (Calgary North.) Edmund Morris (Halifax) was the only Conservative to abstain.

${ }^{46}$ Saywell, Canadian Annual Review for 1963, 302.

${ }^{47}$ Ibid., 304.

${ }^{48}$ Ibid., 302.
} 
the preceding elections to brand their leader as a hard-lined Cold Warrior) continue to remain unclear. Beyond a campaign leaflet that promised the Conservatives would "Strive for World Peace and Disarmament," the Tories rarely justified their ambivalence toward nuclear weapons as a commitment to nonproliferation, with Diefenbaker insinuating that the matter was more about ensuring American interests did not dictate Canadian defence policy. ${ }^{49}$

Like Diefenbaker, Pearson had been initially hesitant to come down hard on either side of the nuclear debate. While he had once said that he would "rather be red than dead," by the start of the campaign Pearson had decided that Canada must maintain its existing nuclear commitments while simultaneously opposing "any extension of the number of nations possessing offensive nuclear bombs of independent nuclear forces." ${ }^{50}$ On its face the Liberal leader's decision to adopt an explicitly pro-nuclear stance (even a qualified one) is perplexing. Such categorical support for Canadian possession of weapons of mass destruction hardly appears to conform to the Liberals" previous "golden age" rhetoric and commitment to foster a "creative peace" in the face of Soviet aggression. ${ }^{51}$ Yet this assessment overlooks other key tenets of the Liberals' ongoing foreign policy, as the Grits had maintained in past elections that Canada must continue to "[work] steadily and cooperatively with our allies" in order to effectively promote global peace.${ }^{52}$ The 1963 Liberal platform uses this very rationale to justify the party's pronuclear policy, in a passage that is worth repeating here in its entirety:

A nuclear war cannot be won. With two great power blocs capable of destroying each other, the only defence is to prevent war starting. Until there is mutual disarmament, with an effective inspection and control, this means that we must have sufficient strength to make sure that no one will attack, because the aggressor knows that he will be destroyed along with his victim. To provide such deterrent strength, we must co-

\footnotetext{
${ }^{49}$ Carrigan, Canadian Party Platforms, 304; J.L. Granastein, A Man of Influence: Norman A. Robertson and Canadian Statecraft, 1929-1968 (Toronto: Deneau Publishers, 1981), 355.

${ }^{50}$ Carrigan, Canadian Party Platforms, 302.

${ }^{51}$ Ibid., 244.

${ }^{52}$ Ibid., 269.
} 
operate closely with our friends in the free world. A country such as Canada cannot defend itself alone. Our defence effort means our contribution to the North Atlantic Alliance. It is collective defence, not defence in isolation. In our policies for external affairs and defence we therefore must get on well with our friends and work closely with them. ${ }^{53}$

The Liberals' position on nuclear weapons consequently sought to strike a balance between the pressing realities of the Cold War and the party's proclivity toward a more constructive foreign policy. In weighing Pearson's pro-nuclear stance, historian Robert Bothwell reflected that "Politicians must live in the here and now, and what Canada confronted was an actual problem with its allies and alliances. NATO was a cornerstone of Canada's foreign policy and an asset in its foreign relations." ${ }^{54}$ The Liberal platform further maintained that "When Canada is again carrying out her commitments, Canada will again be in a position of influence with her allies."55 On the issue of nuclear arms, Pearson and the Liberals thus sought adapt their position to the shifting expectations of the Cold War without abandoning the overarching symbolism that had defined their earlier foreign policy rhetoric.

It is tempting to conclude that the nuclear issue was the key factor in 1963 that led to the Liberal's minority victory and the Tories' relegation back to the opposition benches. ${ }^{56}$ Yet this would be an overly cursory assessment. At its core the question of nuclear armament was a lens through which the Liberals sought to frame the acute indecisiveness that had characterized the later years of Diefenbaker's premiership. ${ }^{57}$ In recounting the non-confidence motion that had brought the Conservatives down, Pearson himself offered the following evaluation:

\footnotetext{
${ }^{53}$ Carrigan, Canadian Party Platforms, 301.

${ }^{54}$ Robert Bothwell, Alliance and Illusion: Canada and the World, 1945-1984 (Vancouver: UBC Press, 2007$), 172$.

${ }^{55}$ Carrigan, Canadian Party Platforms, 302.

${ }^{56}$ Carrigan, Canadian Party Platforms, 293. The final seat counts for all parties were: Conservatives, 95; Liberal, 129; New Democratic, 17; Social Credit, 24.

${ }^{57}$ Bothwell, Alliance and Illusion, 174.
} 
I consider government mishandling of the defence issue and the resultant disintegration of their ranks was the main reason for their downfall. But there was more to it than that. ... Confidence in the government had not been restored after their narrow escape in the 1962 election - indeed, quite the contrary. No budget had been brought down. There was a growing belief that Diefenbaker was largely to blame for the deterioration of our relations with the United States... ${ }^{58}$

The debate over nuclear weapons offered Pearson an opportunity to challenge the more general disposition with which Diefenbaker had approached governance. Indeed, during the latter stages of the campaign signs had begun to emerge that the public's interest in the nuclear issue was waning, with it appearing that Diefenbaker (in spite of the relentless criticism he had endured since the writ dropped) was on track to be reelected. The Grits subsequently shifted the focus of their messaging to the broader issue of domestic leadership, with Pearson promising "sixty days of decision" and a bold legislative agenda should Canadians return the Liberals to power. ${ }^{59}$

To the same extent that it had dominated the 1963 campaign, foreign policy in the 1965 election was virtually non-existent. ${ }^{60}$ For the most part this was unsurprising. In general, the 1965 campaign (the third in four years) was characterized by weary politicians and apathetic voters. By this point there was little desire amongst the electorate or the political class to even debate domestic issues, much less external ones. Pearson, who had experienced bouts of exhaustion throughout the 1963 election found minority government as a whole to be a frustrating experience. The new prime minister relished the prospect of governing without having to worry about Diefenbaker obstructing his agenda, and predicted that even if the

\footnotetext{
${ }^{58}$ Lester B. Pearson, Mike: The Memoirs of the Right Honourable Lester B. Pearson - Volume 3, 1957-1968 (Toronto: University of Toronto Press, 1975), 75-76.

${ }^{59}$ Walter L. Gordon, A Political Memoir (Toronto: McClelland and Stewart, 1977), 127.

${ }^{60}$ John Saywell, Canadian Annual Review for 1965 (Toronto: University of Toronto Press, 1966), 268.
} 
Liberals were elected with another minority that the Tory leader would be driven from politics once and for all. ${ }^{61}$

On the counsel of his advisers Pearson called an election for November 8. During the campaign neither Pearson nor Diefenbaker made any major speeches on foreign policy, and the presence of the nuclear arms issue was at best, intermittent. ${ }^{62}$ The core of the Liberal's message remained focused throughout the election on their appeal for a majority government, with their official platform touching on defence policies briefly. ${ }^{63}$ On the issue of nuclear arms, the platform only broached the subject insofar as it predicted that "an all-out thermonuclear war [is] now highly unlikely." ${ }^{64}$ Beyond this defence was mostly discussed with regard to how the Liberal's decision to integrate the three units of Canada's armed forces would help to cut expenses and ensure "that Canada will have a highly mobile, flexible force capable of going anywhere, engaging in a wide variety of peacekeeping and peace-restoring operations..." ${ }^{65}$ This reference to peacekeeping should not go unnoticed, as it underscores how even when external affairs were a relatively low priority for the Liberals that the party continued to frame their foreign policies around advancing this central "golden age" doctrine.

The Conservatives' official platform arguably diminished the party's focus on foreign policy even more than the Liberals: the closest the Tories got to discussing foreign policy was in their section on international trade, which although mostly being viewed as a way to increase Canada's prosperity, was held up as "a bridge to peace." ${ }^{66}$ Beyond this their platform was focused largely on "welfarist manifestos" and Diefenbaker's promise to strengthen

\footnotetext{
${ }^{61}$ English, The Worldly Years, 304.

${ }^{62}$ Saywell, Canadian Annual Review for 1965, 268.

${ }^{63}$ Davey, The Rainmaker, 105.

${ }^{64}$ Carrigan, Canadian Party Platforms, 316

${ }^{65}$ Ibid.

${ }^{66}$ Ibid., 323
} 
national unity by calling "a great National Conference on Confederation" to amend the British North America Act as a Canadian statute. ${ }^{67}$ This theme of national unity served as one of Diefenbaker's two main messages on the hustings, with the other being the "scandals" and conflicts of interest which had beset the Liberal government since the previous election. ${ }^{68}$ Nevertheless, both parties struggled to gain traction throughout the 1965 election. Canadians had shown no desire to go back to the polls before Pearson called an election, and the final seat count reflected this indifference: the 1965 Parliament was almost identical to its predecessor, with the Liberals forming another minority government at 131 seats and the Conservatives remaining in official opposition with ninety-five seats. ${ }^{69}$

In the four Canadian elections held between 1958 and 1965 foreign policy was used by both the Liberal and Progressive Conservative parties to further their respective political brands. During the 1958 and 1962 elections, the foreign policy of Diefenbaker's Conservatives reflected the party's general suspicion of American foreign interests, veneration for Canada's British heritage and Cold Warrior mentality. In contrast, Liberal foreign policy rhetoric in 1958 and 1962 highlighted Canada's emerging role as an independent middle power and commitment to multilateralism and peacekeeping. Pearson and the Grits repeatedly implied that this "vital aspect of [Canada's] nationhood" owed its thanks to the policies of past Liberal governments, and subsequently sought to position themselves as the purer political embodiment of this "special national character." The debate in 1963 over nuclear weapons further saw an entrenchment of the Tories' perceived anti-Americanism (albeit at the puzzling expense of their Cold Warrior credentials) and the Liberals' emphasis

\footnotetext{
${ }^{67}$ Smith, Rogue Tory, 533; Carrigan, Canadian Party Platforms, 320-321.

${ }^{68}$ Smith, Rogue Tory, 534.

${ }^{69}$ Carrigan, Canadian Party Platforms, 308; The final seat-counts for the other parties were: New Democratic, 21; Social Credit, 5; Ralliement Créditiste, 9; other, 2.
} 
on upholding Canada's international responsibilities. Despite that the Grits' pro-nuclear position appeared to prima facie conflict with the party's bent toward constructive peace, the Liberals held that Canada must live up to its nuclear commitments were it to re-attain to its positive influence on the world stage. Even in 1965, when foreign policy's respective importance to both major parties was almost negligible, the Liberals continued to place a high priority on established "golden age" policies such as peacekeeping.

By the time Pearson stepped down as prime minister in 1968 "golden age" imagery and language had become crucial to how Canadians discussed their country's place in the world. Indeed, when Pearson's successor Pierre Trudeau promised in the 1968 election to move Canada away from its role as a "helpful fixer," this was widely interpreted as a departure from a foreign policy tradition which had come to be viewed as being both quintessentially Canadian and Liberal. ${ }^{70}$ Whether this was an accurate historical depiction of Canadian foreign policy is beside the point; such exceptionalism had become an effective way for Canadians to distinguish themselves from other nations and the Liberals from their political rivals. While this paper's limited scope does not allow for the assertion that the notion of a Canadian diplomatic "golden age" came about entirely because of Liberal political rhetoric, the preceding case studies all demonstrate how "golden age" symbolism was a key part of the Liberal Party's brand throughout Pearson's tenure as leader. In the very least, a compelling case can be made that during that these elections the Grits actively contributed to "golden age" mythmaking and helped (at least in part) to imbue such a notion in Canada's political consciousness.

\footnotetext{
${ }^{70}$ Kristopher E. Kinsinger, “A Passing Interest: The Foreign Policy of Pierre Trudeau 1968-1984,” Waterloo Historical Review 7 (2015): 3, accessed November 28, 2015, http://dx.doi.org/10.15353/whr.v7.31
} 


\section{Bibliography}

Bothwell, Robert. Alliance and Illusion: Canada and the World, 1945-1984. Vancouver: UBC Press, 2007.

Carrigan, Owen D. edit. Canadian Party Platforms, 1967-1968. Toronto: Copp Clark Publishing Company, 1968.

Davey, Keith. The Rainmaker: A Passion for Politics. Toronto: Stoddart, 1986.

Diefenbaker's Statements and Promises, 1958. Ottawa: National Liberal Federal, 1958. Accessed December 2, 2015, https://www.poltext.org/sites/poltext.org/files/plateformes/can1958pc_plt_29032012_161 629.pdf.

Diefenbaker, John G. One Canada: Memoirs of the Right Honourable John G. Diefenbaker Volume Two: The Years of Achievement, 1956-1962. Scarborough: Signet, 1976.

Diefenbaker, John G. One Canada: Memoirs of the Right Honourable John G. Diefenbaker Volume Three: The Tumultuous Years, 1962-1967. Scarborough: Signet, 1977.

Donaghy, Greg. "Canadian Diplomacy and the Offshore Islands Crisis, 1954-1955: A Limited National Interest.” International Journal 68, no. 2 (2013): 242-254.

Donaghy, Greg, edit. Documents on Canadian External Relations: Vol. 24. Ottawa: Department of External Affairs, 2003.

English, John. The Worldly Years: The Life of Lester Pearson, 1949-1972. Toronto: Alfred A. Knopf Canada, 1992.

Getting Things Done for Canadians - An Outline of Progressive Conservative Government Action, 1957-1962: The Greatest Era of Expansion in Canada's History. Ottawa: Progressive Conservative Party of Canada, 1962. Accessed December 2, 2015; https://www.poltext.org/sites/poltext.org/files/plateformes/can1962pc_bilan_18072011_1 55924.pdf.

Gordon, Walter L. A Political Memoir. Toronto: McClelland and Stewart, 1977.

Granastein, J.L. A Man of Influence: Norman A. Robertson and Canadian Statecraft, 1929-1968. Toronto: Deneau Publishers, 1981.

Hiller, Norman, edit. Pearson: The Unlikely Gladiator. Montreal and Kingston: McGill-Queen's University Press, 1999.

Kinsinger, Kristopher E. “A Passing Interest: The Foreign Policy of Pierre Trudeau 1968-1984.” Waterloo Historical Review 7 (2015). Accessed November 28, 2015, http://dx.doi.org/10.15353/whr.v7.31 
Mackenzie, Hector. "Knight Errant, Cold Warrior or Cautious Ally? Canada on the Untied Nations Security Council, 1948-1949.” Journal of Transatlantic Studies 7, no. 4 (2009): 453-475.

Martin, Paul. A Very Public Life - Volume II: So Many Worlds. Toronto: Deneau Publishers, 1985.

McKercher, Asa. "The Centre Cannot Hold: Canada, Colonialism and the 'Afro-Asian Bloc' at the United Nations, 1960-62." The Journal of Imperial and Commonwealth History 24, no. 2 (2014): 329-349.

Newman, Peter C. Renegade in Power: The Diefenbaker Years. Toronto: McClelland and Stewart, 1964.

Newman, Peter C. The Distemper of Our Times: Canadian Politics in Transition: 1963-1968. Toronto: McClelland and Stewart Limited, 1968.

Pearson, Leter B. Mike: The Memoirs of the Right Honourable Lester B. Pearson - Volume 3, 1957-1968. Toronto: University of Toronto Press, 1975.

National Liberal Convention - Report on the Proceedings. Ottawa: National Liberal Federation of Canada, 1961.

Saywell, John T, edit. Canadian Annual Review for 1962. Toronto: University of Toronto Press.

Saywell, John, edit. Canadian Annual Review for 1963. Toronto: University of Toronto Press, 1964.

Saywell, John, edit. Canadian Annual Review for 1965. Toronto: University of Toronto Press, 1966.

Smith, Denis. Rogue Tory: The Life and Legend of John G. Diefenbaker. Toronto: MacFarlane Walter \& Ross, 1995.

Stursberg, Peter. Lester Pearson and the American Dilemma. Toronto: Doubleday Canada Limited, 1980.

Thordarson, Bruce. Lester Pearson: Diplomat and Politician. Toronto: Oxford University Press, 1974. 